\title{
Distribution and importance of some endemic Astragalus L. species in semi-arid environmentally sensitive areas: a case study from northern Turkey
}

\author{
Ebru Gül ${ }^{1 * i \mathrm{D}}$, Melda Dölarslan ${ }^{1 \mathrm{iD}}$
}

${ }^{1}$ Çankııı Karatekin University, Çankırı, Turkey

FOREST ECOLOGY

\begin{abstract}
Background: The objective of this study was to determine the distribution of some endemic species of the genus Astragalus L. (Astragalus anthylloides Lam., Astragalus lycius Boiss. and Astragalus xylobasis var. angustus (Freyn \& Sint.) Freyn \& Bornm.) species, and the interaction between soil, climatic characteristics and desertification risk which affect the distribution of these species in the semi-arid environment of Çankırı, northwest Turkey. During the vegetation period in 2017, soil and plant samples were collected from 180 points. Desertification risk (DR) and environmentally sensitive area index (ESAI) were calculated for each sampling point using the desertification indicator system for Mediterranean Europe (DIS4ME)
\end{abstract}

Results: According to the DIS4ME system in the forest areas, DR values for A. anthylloides and A. lycius were lowest with 0.49 (no desertification risk) and highest with 3.73 (moderate desertification risk), and with an average of 2.20 in the field (low desertification risk). For A. xylobasis var. angustus in grassland, the DR values ranged from a low of 5.01 to a high of 5.42. The ESAI values ranged from 1.34 to 1.50 in the forest areas where the species $A$. anthylloides and A. lycius were distributed, and they ranged between 1.33 and 1.47 for $A$. xylobasis var. angustus in the grassland areas. The results of the analysis between the DR values and Astragalus L. species changes according to the land use types and plant distribution.

Conclusion: When the relationships between all three of these endemic species' DR values are evaluated together, they emerged as the best plant species indicator for determining desertification status.

Keywords: Çankırı-Yapraklı, Endemism, Astragalus L., Soil Properties, Desertification Risk

\section{HIGHLIGHTS}

Hypothesis of research: determination of indicator plants for combating desertification. Astragalus L. species have different desertification risk.

Environmental sensitivity of grassland has increased due to deterioration of vegetation. Desertification risk to grassland changes depending on environmental factors.

GÜL, E.; DÖLARSLAN, M. Distribution and importance of some endemic Astragalus L. species in semi-arid environmentally sensitive areas: a case study from northern Turkey. CERNE, v. 27, e-102559, doi: 10.1590/01047760202127012559 


\section{INTRODUCTION}

Desertification, which is one of the largest global environmental problems faced today, has become increasingly important in the last 50 years. Dregne (2002) indicated that desertification and land degradation is not a new phenomenon, yet it is a problem that previously occurred with small, undetected changes for centuries. Many definitions have been stated about the concept of desertification and its various effects simply put, desertification is land degradation that occurs as a result of climate change and human influence, especially in arid and semi-arid areas (UNCCD, 1995; Kosmas et al., 2003; Adamo and Crews-Meyer, 2006; Camcı Çetin et al., 2007, Türkeş, 2012). Desertification can lead to decrease in soil fertility, destruction of vegetation, and ultimately desert-like conditions (Mabbutt, 1984).

In recent years, land degradation due to climate change and the decrease in plant diversity has accelerated the studies of its impact around the world, including Turkey; as well as studies on the necessary measures to prevent and reverse desertification (Dregne, 2002; Huang and Siegert, 2006; Kosmas et al., 2006; Bouabidet al., 2010; Rasmy et al., 2010; Brandt and Geeson 2015; Tübitak 2015; Gül and Erşahin, 2017, 2019). Various methods and indicators have been developed for determination of desertification processes (Kharin et al., 1985; Kosmas et al., 1999; Desertlinks, 2004; Kosmas et al., 2006; Brandt and Geeson, 2015). One of these methods is the desertification indicator system for Mediterranean Europe (DIS4ME), which uses local indicators (Vanmaercke et al., 2011; Geeson et al., 2014). This system's criterion utilizes theoretical scores and expert opinions. Dölarslan et al. (2015) and Gül and Erşahin (2019) used the DIS4ME system to determine the desertification risk (DR) in differently used land areas with semi-arid climatic characteristics and found significantly strong relationships between the calculated risk values and the observed values. The DIS4ME method, which was originally developed for Mediterranean countries, it optimal for us in Turkey. The key factor in the determination of desertification is the soil trapped by vegetation and continuous plant coverage (Uluocak 1980). Woody and herbaceous taxa, which contain the surface, are important for soil protection, and guard against erosion, land degradation and the desertification processes. An et al. (2007) specified that the distribution of plant species was affected by degrees of desertification.

Some plant species, which show resistance or resilience to desertification, still show changes in the quantity and composition of the perennial plant vegetation (De Soyza et al., 1998). An et al. (2007) stated that natural plant composition tends to change with desertification. For example, species of the genus Astragalus L., which are herbaceous taxa, protect the soil in sloping areas with strong root systems and vegetation, which fights erosion (Niknam and Ebrahimzadeh, 2002) even in extreme weather conditions. Some Astragalus L. species, which can have roots 3-5 m deep, can even prevent erosion and protect the soil even in severe winds and floods (Kaçmaz, 2007; Kadıoğlu et al., 2008, Demir and Keskin, 2016). Zhao et al. (2017) stated that Astragalus adsurgens Pall. has a significant impact on soil erosion control compared to bare soils. However, Kadıoğlu et al. (2008) have indicated that Astragalus L. species are under the threat of global warming and desertification, emphasizing the importance for protection from human factors. The present study was carried out to (a) identify the distribution of three endemic species of the genus Astragalus L. and (b) use these species as indicators for the assessment of the extent of desertification in the semi-arid environment of Çankırı, northwest Turkey.

\section{MATERIAL AND METHODS}

The observation sites and sampling points were determined according to the distribution of three endemic species of the genus Astragalus L. species in the study area. Both of the $A$. anthylloides and $A$. lycius species are commonly distributed under the forest canopy, while $A$. xylobasis var. angustus is distributed in grassland area. From April to September 2017, at the observation site, soil and plant samples were collected concurrently a total of 180 sampling points from two different land use types.

\section{Study Area}

The study area is located in Çankırı province Yapraklı district, north-central Anatolia, Turkey (40 $45^{\prime} 00^{\prime \prime}-40^{\circ} 52^{\prime}$ $30^{\prime \prime} \mathrm{N}$ and $33^{\circ} 37^{\prime} 30^{\prime \prime}-33^{\circ} 52^{\prime} 30^{\prime \prime} \mathrm{E}$; Fig. 1). It is located in Çankırr: G31-b3 and G31-b4 layouts on a 1/25 000 scale topographical map, the elevation ranges from 1128 to 1694 m (Fig. 2, shown in supplementary data) above sea level and the main study area is southeast and northwest. According to the climatic data of Yapraklı district, the average annual temperature is $9.1{ }^{\circ} \mathrm{C}$, ranging from $-2.3^{\circ} \mathrm{C}$ in January (minimum) to $17.8{ }^{\circ} \mathrm{C}$ in July-August (maximum); annual precipitation is $538.1 \mathrm{~mm}$, and the minimum is $16.4 \mathrm{~mm}$ in September. The main soil groups in the region are Entisols and Inceptisols (Gül and Erşahin, 2019). The parent materials consist of limestone, sandstone, conglomerate, and red chalk.

\section{Plant Sampling}

Study area is located A4 square according to the grid system of P.H. Davis $(1965 ; 1988)$ and Iranian-Turan region in phytogeographic respect (Davis, 1965; 1988). To determine the distribution of each endemic $A$. anthylloides, A. lycius, and A. xylobasis var. angustus species (Fig. 3 , shown in supplementary data), sampling was done at 60 points in $1 \mathrm{~m}^{2}(1 \times 1)$ quadrates. It investigated 180 sampling points. Soil and plant sampling were carried out concurrently. Plant samples were collected and recorded periodically from April to September (the vegetation period) 2017 in each quadrat. The collected plant specimens were intact, full of leaves, in bloom, and non-damaged; maturity of fruits and seeds were noted. In each quadrat, the number of Astragalus L. species and plant cover (\%) were determined in the study area. 


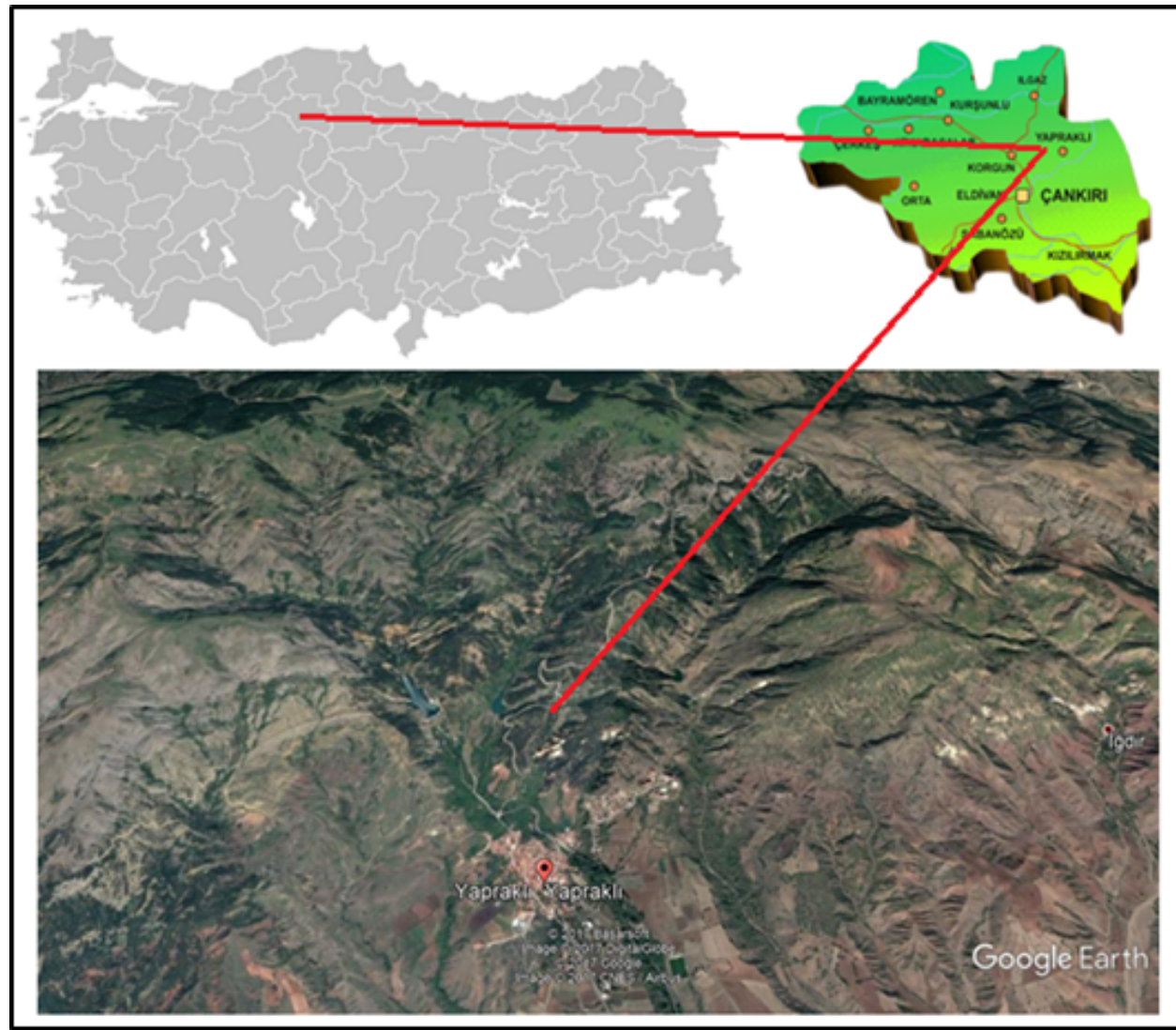

Fig. 1 The study area.

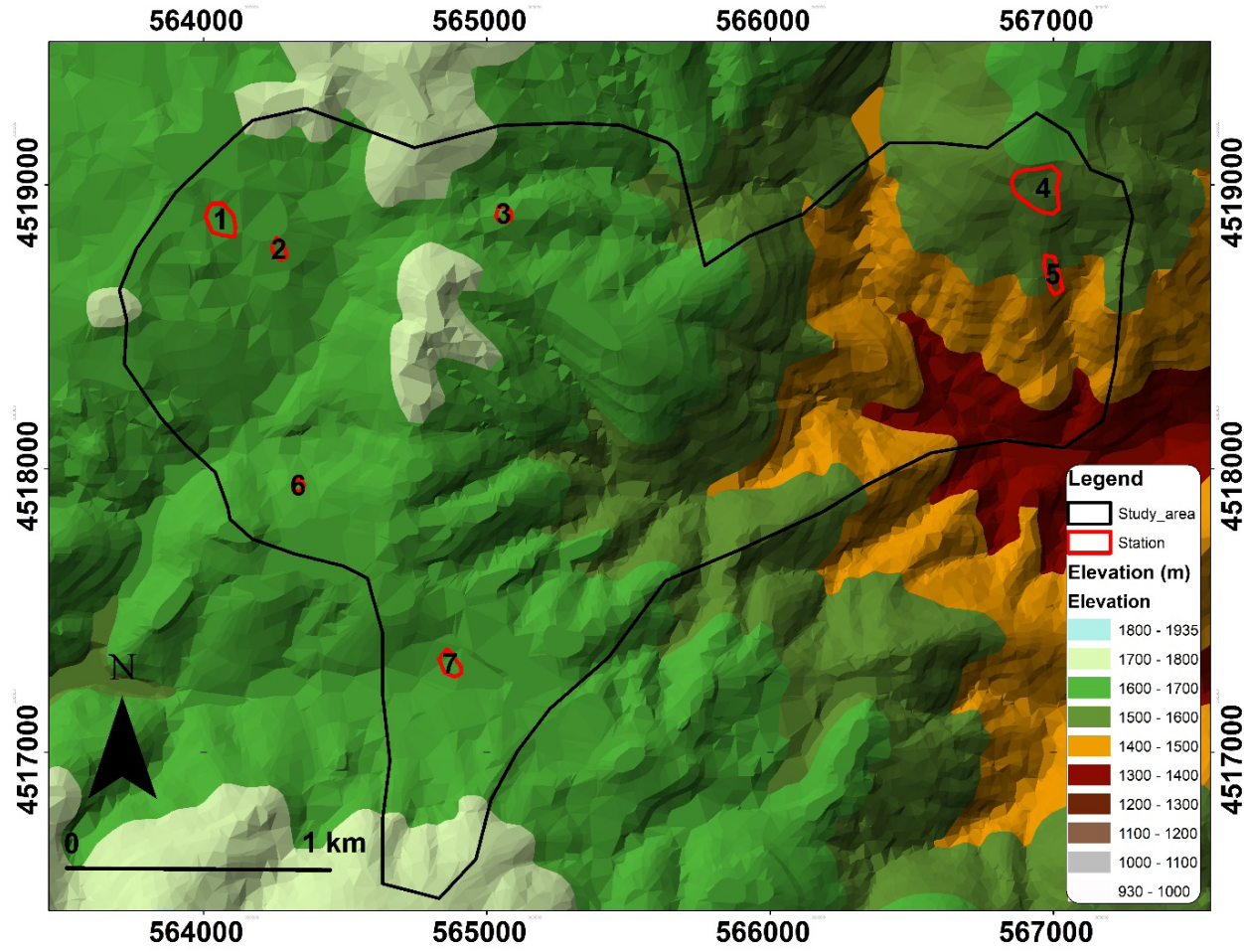

응

¿े Fig. 2 Elevation map 5 of the study area with sampling area. 
A

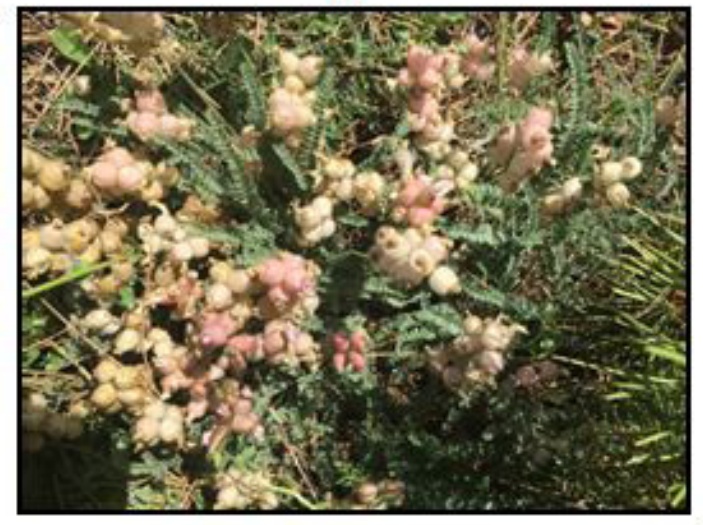

B

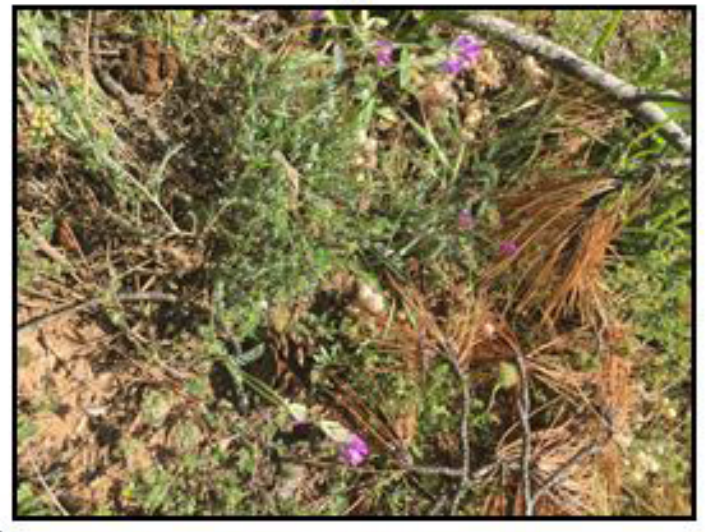

$\mathrm{C}$

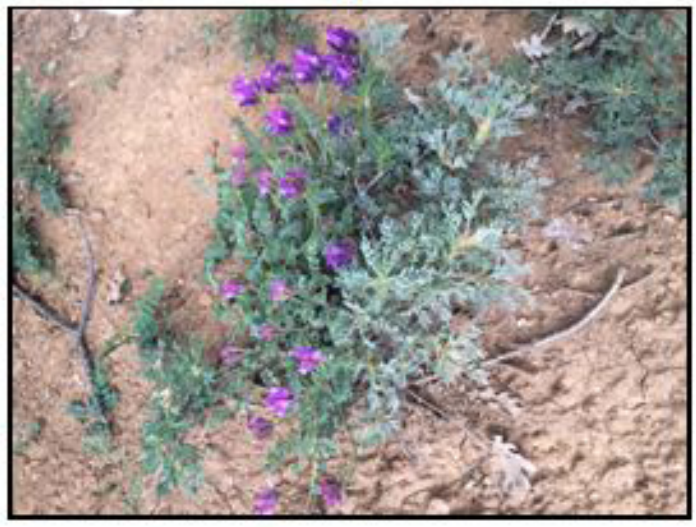

Fig. 3 Endemic species of the genus Astragalus L. A) Astragalus anthylloides Lam.; B) Astragalus lycius Boiss.; and C) Astragalus xylobasis Freyn \& Bornm. var. angustus Freyn \& Bornm.

\section{Soil Sampling and Laboratory Analysis}

Soil samples were collected from topsoil (depth of $0-30 \mathrm{~cm})$ at August of 2017 in $1 \mathrm{~m}^{2}(1 \times 1)$ quadrat to determine the general soil properties of Astragalus L. species. For each Astragalus L. species, 60 soil samples were collected in a total of 180 sampling points. When soil samples were collected in each sampling point, the upper layer of soi surface (approximately 1-3 $\mathrm{mm}$ ) was cleaned from rock and plant debris (pine core, tree branch, leaf, etc). Soil samples were air-dried, cleaned, crushed and sieved through a 2.0 $\mathrm{mm}$ screen in the laboratory (Çankırı Karatekin University, Forestry Faculty, Soil Science and Ecology Laboratory) and stored in plastic bags. Particle size (sand, silt, clay contents) was determined by the Bouyoucos Hydrometer method (Gee and Bauder, 1986). Soil reaction (pH) and electrical conductivity were determined with a glass electrode in soildistilled water suspension in the ratio of 1:5, (McLean, 1982) using a calibrated $\mathrm{pH}$ meter (HACH HQ40d Portable Multi Meter pH, Conductivity, Salinity, TDS, (DO), ORP Analysis Instruments). Soil organic matter (SOM) was measured modified by Jackson's Walkley-Black method as described by Nelson and Sommers (1982). Bulk density (BD) was measured by the core method (Blake and Hartge, 1986) using a volume weight roller $\left(100 \mathrm{~cm}^{3}\right)$ and calcium carbonate $\left(\mathrm{CaCO}_{3}\right)$ content determined according to Nelson (1982) in each soil sample.
Modeling the Environmentally Sensitive Area Index (ESAI)

The DIS4ME method was developed by DESERTLINK project (Desertlinks, 2004) and was one of the first projects developed with a website for researches concerning desertification (Geeson et al., 2014). DIS4ME was created to determine the risk of desertification in Mediterranean countries and provides information on 148 desertification indicators for different land use types (Desertlinks, 2004). It is designed to give a broad spectrum of information to a variety of users (scientists, politicians and farmers). The method can be used to 1) identify where desertification is a problem, 2) assess the level of criticality of the desertification problem, and 3) better understand desertification processes and how they will respond to biophysical and socio-economic changes (Vanmaercke et al., 2011; Geeson et al., 2014; Brandt and Geeson, 2015). The DIS4ME method also provides an opportunity to calculate the environmentally sensitive area index (ESAI). The ESAI is a composite index, which consists of more than 10 variables of climate, vegetation, and soil indicators (Morianouet al., 2018) and procedures to determine the desertification risk (DR). The ESAI methodology has been applied to determine desertification risk in Turkey (Dindaroğlu, 2015; Budak et al., 2018; Gül and 
Erşahin, 2017, 2019) and studies are still being conducted on land degradation in semi-arid areas of Turkey.

It is important to determine the desertification sensitivity of areas in order to identify the ESAI according to climate and land use. ESAI is closely related to various environmental factors such as climate, vegetation, soil, and management (socio-economic factors) (Morianou et al., 2018). In this study, DIS4ME method was utilized to determine DR and ESAI in two different land use types (forest and grassland) using the distribution of some endemic species of the genus Astragalus L. (A. anthylloides, $A$. lycius and Astragalus xylobasis var. angustus). Nearly 15 indicators including the quality of soil, climate, vegetation, and management practices were used to determine the DR and
ESAI. Information about these indicators was determined or collected from various sources (Tab. 1). After collecting all the data, the ESAI was calculated using equations 1, 2, 3, 4 and 5 (Desertlinks, 2004; Parvari et al. 2011). In the

$$
\begin{aligned}
& \mathrm{S}_{Q l}=(\text { parent material } \times \text { texture } \times \text { soildepth } \times \text { slope })^{1 / 4} \\
& \mathrm{C}_{Q I}=(\text { rainfall } / \text { potentialevapotranspiration })^{\frac{1}{2}} \\
& \mathrm{~V}_{Q I}=(\text { fire risk } \times \text { erosion protection } \times \text { aridity resistance } \times \text { plant Cover })^{\frac{1}{4}} \\
& \mathrm{M}_{Q I}=(\text { land use type } \times \text { management practices })^{\frac{1}{2}} \\
& E S A I=(S Q I \cdot C Q I \cdot V Q I \cdot M Q I)^{\frac{1}{1}}
\end{aligned}
$$

\begin{tabular}{|c|c|c|c|c|}
\hline Category & Indicator & Classes & Index & Method of obtaining data \\
\hline \multirow{12}{*}{$\begin{array}{l}\text { Vegetation } \\
\text { quality }\end{array}$} & \multirow{3}{*}{$\begin{array}{c}\text { Plant Cover } \\
(\%)\end{array}$} & $<10$ & 1.0 & \multirow{3}{*}{$\begin{array}{l}\text { Field observations, The degree of vegetation covering the } \\
\text { soil was determined. }\end{array}$} \\
\hline & & $/ 10-40$ & 1.8 & \\
\hline & & $1>40$ & 2.0 & \\
\hline & \multirow{5}{*}{ Erosion Control } & Low & 1.0 & \multirow{5}{*}{$\begin{array}{l}\text { Field observation, It has been determined to take into } \\
\text { account the protection measures taken in the area. }\end{array}$} \\
\hline & & Moderate & 1.3 & \\
\hline & & Low to moderate & 1.6 & \\
\hline & & High & 1.8 & \\
\hline & & Very High & 2.0 & \\
\hline & \multirow{4}{*}{ Fire Protection } & Low & 1.0 & \multirow{4}{*}{$\begin{array}{l}\text { Field observation, It has been determined to take into } \\
\text { account the protection measures taken in the area. }\end{array}$} \\
\hline & & Moderate & 1.3 & \\
\hline & & High & 1.6 & \\
\hline & & Very High & 2.0 & \\
\hline \multirow{24}{*}{ Soil quality } & \multirow{4}{*}{$\begin{array}{l}\text { Soil depth } \\
\quad(\mathrm{cm})\end{array}$} & $\operatorname{deep}(>75 \mathrm{~cm})$ & 1.0 & \multirow{4}{*}{$\begin{array}{l}\text { Field observation, it was determined using auger from } \\
\text { sampling instruments. }\end{array}$} \\
\hline & & moderate $(75-30 \mathrm{~cm})$ & 2.0 & \\
\hline & & shallow $(15-30 \mathrm{~cm})$ & 3.0 & \\
\hline & & very shallow $(<15 \mathrm{~cm})$ & 4.0 & \\
\hline & \multirow{4}{*}{$\begin{array}{c}\text { Slope } \\
(\%)\end{array}$} & $<6$ & 1.0 & \multirow{4}{*}{ It was determined using an inclinometer. } \\
\hline & & $6-18$ & 1.2 & \\
\hline & & $18-35$ & 1.5 & \\
\hline & & $>35$ & 2.0 & \\
\hline & \multirow{2}{*}{ Slope Aspect } & North, NW, NE, plain & 1.0 & \multirow{2}{*}{ It was determined using Global Positioning System (GPS). } \\
\hline & & South, SW, SE & 2.0 & \\
\hline & \multirow{3}{*}{ Drainage } & well drained & 1.0 & \multirow{3}{*}{$\begin{array}{l}\text { It was determined considering water color and depth of } \\
\text { groundwater (Desertlinks 2004). }\end{array}$} \\
\hline & & imperfectly & 1.2 & \\
\hline & & poor drained & 2.0 & \\
\hline & \multirow{4}{*}{ Soil Texture } & $\mathrm{L}, \mathrm{SCL}, \mathrm{SL}, \mathrm{LS}, \mathrm{CL}$ & 1.0 & \multirow{4}{*}{$\begin{array}{l}\text { Laboratory analysis, Bouyoucos hydrometer method (Gee } \\
\qquad \text { and Bauder 1986) }\end{array}$} \\
\hline & & SC, SiL, SiCL & 1.2 & \\
\hline & & $\mathrm{Si}, \mathrm{C}, \mathrm{SiC}$ & 1.6 & \\
\hline & & & 2.0 & \\
\hline & \multirow{4}{*}{ Parent Material } & $\begin{array}{c}\text { Shale, schist, basic, ultrabasic, } \\
\text { conglomerates, unconsolidated, clays; } \\
\text { marl (with natural veg.) }\end{array}$ & 1.0 & \multirow{4}{*}{ Field observation } \\
\hline & & Limestone, marble, granite, rhyolite, & & \\
\hline & & $\begin{array}{l}\text { ignimbrite, gneiss, siltstone, sandstone, } \\
\text { dolomite: }\end{array}$ & 1.7 & \\
\hline & & Marl, Pyroclastic. & 2.0 & \\
\hline & \multirow{3}{*}{$\begin{array}{l}\text { Rock Fragments } \\
\qquad(>6 \mathrm{~mm})\end{array}$} & $>60$ & 1.0 & Field observation, It was determined by taking into account \\
\hline & & $20-60$ & 1.3 & the area occupied by the rock fragments on the surface of \\
\hline & & $<20$ & 2.0 & the land. \\
\hline & Mean Annual & $>650$ & 1.0 & \\
\hline & & $280-650$ & 2.0 & Calculated by interpolating from nearby stations. \\
\hline & precipitation & $<280$ & 4.0 & \\
\hline & & $<50$ & 1.0 & It was calculated from the Bagnouls-Gaussen index using \\
\hline Climate quality & & $50-75$ & 1.1 & the following equation. $B G K I=\sum^{12}\left(2 t_{i}-P_{i}\right) k_{i}$ \\
\hline & & $75-100$ & 1.2 & . \\
\hline & Aridity index & $100-125$ & 1.4 & $\mathrm{ti}=$ is the mean air temperature for a month $\mathrm{i}$ in $0^{\circ} \mathrm{C} \mathrm{Pi}=\mathrm{s}$ \\
\hline & & $125-150$ & 1.8 & the total precipitation for a month $\mathrm{i}$ in $\mathrm{mm}$; $\mathrm{ki}=$ represents \\
\hline & & $>150$ & 2.0 & the proportion of the month during which $2 \mathrm{ti}-\mathrm{Pi}>0$. \\
\hline & & Low & 1.0 & was determined by taking into consideration the supports \\
\hline & Land use intensity & Moderate & 1.5 & was deter \\
\hline Management & & High & 2.0 & received by the land owners and the state supports. \\
\hline practices & Policy & Low & 1.0 & \\
\hline & enforcement & Moderate & 1.5 & \\
\hline & entorcement & High & 2.0 & \\
\hline
\end{tabular}

Tab. 1 The list of the indicators used for determining the environmentally sensitive area index (ESAI) (Desertlinks 2004, Brandt and Thornes 1996, Kosmas et al. 1999, Kosmas et al. 2006, Brandt and Geeson 2015, Budak et al. 2018, Gül and Erşahin 2019). 
equation, $\mathrm{S}_{\mathrm{Q}}$ : soil quality index, $\mathrm{C}_{\mathrm{Q}}$ : climate quality index, $\mathrm{V}_{\mathrm{Q}}$ : vegetation quality index, $M_{\mathrm{Q}}$ : management quality index.

Sub-indices used in equations do not have an absolute value. For this reason, calculations are made theoretically by giving score values ranging from 1-2 to index values (Tab 1). Low scores indicate lower land degradation sensitivity, while high scores indicate a higher risk of land degradation. After calculation of ESAI value, the desertification is categorized as follows: ESAI $\leq 1.17$, unaffected; $1.17<$ ESAI $\leq 1.225$, potentially affected; $1.225<$ $E S A I \leq 1.375$, fragile; and $1.375<$ ESAl, critical (Basso et al., 2000; Desertlinks, 2004; Salvati and Bajocco, 2011).

\section{Statistical Analysis}

Descriptive statistics of the data were determined using software SPSS (SPSS Institute Inc., 2012), and the data were analyzed using multivariate statistical analysis. Correlation analysis was applied to test the relationship between the species for each quadrate. In interpreting the relationship between DR and the distribution of Astragalus L. species, the coefficient of correlation was considered.

\section{RESULTS}

\section{Results of Plant Species}

The data related to the plant sampling results of $1 \mathrm{~m}^{2}(1 \times 1)$ quadrates was used in order to determine the distribution of $A$. anthylloides, $A$. lycius, and $A$. xylobasis var. angustus species in the study area (Tab. 2). It was seen that the species numbers vary in terms of both land use and plant association. Although $A$. anthylloides and A. lycius species are distributed in the same land use type, the numbers of the two species are different. $A$. anthylloides (maximum of 27 plants) was more dominant than $A$. lycius (maximum of 11 plants), while the plant number of $A$. anthylloides and A. lycius in quadrates were minimum one (1). The most variability (coefficient of variation) was observed in $A$. anthylloides with $145.09 \%$, while the variability of $A$. lycius was $128.02 \%$.

The presence of $A$. xylobasis var. angustus in the quadrates varied between a minimum of one (1) and a maximum of six (6). The coefficient of variability of this species is $59.63 \%$. When the distribution of the three endemic Astragalus L. species in quadrates was evaluated together, the maximum number of species was detected for type $A$. anthylloides, the lowest variability was detected for A. xylobasis var. angustus. This indicates that the number of plant species may vary in areas with the same climate and topographic structure; A. Iycius, 5\% A. xylobasis var. angustus, and $17 \%$ A. anthylloides. The maximum plant cover for all the three species examined was $100 \%$, while the lowest was A. lycius, $A$. xylobasis var. angustus, and $A$. anthylloides species at 3\%, 5\%, and 17\%, respectively.

\section{RESULTS OF SOIL ATTRIBUTES}

The texture of soil samples of the study area was classified as sandy clay loam (SCL), clay loam (CL) and clay (C) (Soil Survey Staff, 1993, Tab. 3). It was observed that some soil properties such as bulk density (BD), electrical conductivity $(E C)$, salt content, and texture were found to be unchanged, but the soil organic matter (SOM) and $\mathrm{CaCO}_{3}$ content were high in areas where with a distribution of $A$. anthylloides and $A$. lycius. Furthermore, in the areas where $A$. anthylloides and $A$. lycius species are distributed, $\mathrm{CaCO}_{3}$ content is $39.43 \%$ (very calcareous soil) and SOM content is $14.24 \%$ (high), while soils with the distribution of A. xylobasis var. angustus showed $\mathrm{CaCO}_{3}$ content of $13.14 \%$ (calcareous soil) and SOM content varied between $0.16 \%$ (low) and $7.50 \%$ (high). A. anthylloides and A. lycius species are located on moderately sloping topographies (foot slope and toe slope) in pine forest. This is among the reasons for the high content of SOM in the areas where $A$. anthylloides and $A$. lycius species are located. In this topographic structure type, transported material such as plant litter, decomposition of plant, old pinecone, and tree branch accumulation, whereas $A$. xylobasis var. angustus is located on top of the slope which flows and drains to grassland at the bottom of the slope.

A. anthylloides and A. lycius species are distributed where some of the primary rock types are limestone and Pinus nigra Arnold is the dominant forest cover in the area. The limestone contains a high proportion of calcium carbonate $\left(\mathrm{CaCO}_{3}\right)$ in its chemical composition (Yücetürk, 2010), which indicates that the $\mathrm{CaCO}_{3}$ content in the investigated soil is high. A. anthylloides and A. lycius

Tab. 2 Distribution of three endemic Astragalus L. species and other plant species in the study area $(\mathrm{N}=60)$.

\begin{tabular}{|c|c|c|c|c|c|c|c|c|}
\hline Plant taxa & Parameters & Min & Max & Mean & SD & $\begin{array}{c}\text { CV } \\
(\%)\end{array}$ & Kur. & Skew. \\
\hline \multirow{3}{*}{$\mathrm{Aa}$} & Plant Number & 1 & 27.0 & 3.97 & 5.76 & 145.09 & 1.83 & 3.37 \\
\hline & Other species & 0 & 36.0 & 11.21 & 7.49 & 66.82 & 0.97 & 1.14 \\
\hline & Plant Cover (\%) & 17 & 100 & 67.75 & 22.58 & 33.33 & -0.71 & -0.57 \\
\hline \multirow{3}{*}{$\mathrm{Al}$} & Plant Number & 1 & 11.0 & 2.07 & 2.65 & 128.02 & 1.28 & 1.00 \\
\hline & Other species & 0 & 32.0 & 7.65 & 9.05 & 118.34 & 1.35 & 1.10 \\
\hline & Plant Cover (\%) & 3 & 100 & 43.93 & 25.73 & 58.57 & 0.24 & -1.02 \\
\hline \multirow{3}{*}{$A x$} & Plant Number & 1 & 6.0 & 2.18 & 1.30 & 59.63 & 1.25 & 1.24 \\
\hline & Other species & 0 & 74.0 & 25.30 & 20.09 & 79.41 & 0.88 & 0.307 \\
\hline & Plant Cover (\%) & 5 & 100 & 69.30 & 25.92 & 37.40 & -0.72 & -0.22 \\
\hline
\end{tabular}

Aa: Astragalus anthylloides, Al: Astragalus lycius, Ax: Astragalus xylobasis var. angustus, N: sample number, Min: minimum, Max: maximum, SD: standard deviation, CV: coefficient of variation; Kur: Kurtosis; Skew: Skewness 
Tab. 3 Descriptive statistic of soil characteristics and properties.

\begin{tabular}{|c|c|c|c|c|c|c|c|c|c|}
\hline Plant taxa & Parameters & $\mathrm{N}$ & Min & Max & Mean & SD & CV & Kur. & Skew \\
\hline \multirow{8}{*}{$\begin{array}{c}\text { A. anthylloides } \\
\text { and } \\
\text { A. lycius }\end{array}$} & Sand (\%) & 120 & 12.50 & 55.00 & 34.46 & 9.18 & 26.65 & -0.30 & -0.30 \\
\hline & Clay (\%) & 120 & 23.40 & 61.60 & 41.47 & 8.10 & 19.53 & 0.53 & 0.53 \\
\hline & Silt (\%) & 120 & 12.50 & 41.80 & 24.07 & 4.83 & 20.07 & 1.18 & 1.18 \\
\hline & $\mathrm{BD}\left(\mathrm{gr}_{\mathrm{cm}}^{-3}\right)$ & 120 & 1.12 & 1.41 & 1.26 & 0.07 & 5.20 & 0.22 & 0.22 \\
\hline & $\mathrm{CaCO} 3$ (\%) & 120 & 2.92 & 39.43 & 21.27 & 7.86 & 36.97 & -0.68 & -0.68 \\
\hline & SOM (\%) & 120 & 0.15 & 14.24 & 2.80 & 2.12 & 75.67 & 3.83 & 3.83 \\
\hline & $\mathrm{pH}$ & 120 & 6.90 & 7.76 & 7.26 & 0.18 & 2.44 & 0.57 & 0.57 \\
\hline & $E C\left(d S m^{-1}\right)$ & 120 & 0.17 & 2.15 & 1.31 & 0.29 & 22.28 & 0.21 & 0.21 \\
\hline \multirow{8}{*}{$\begin{array}{c}\text { A. xylobasis var. } \\
\text { angustus }\end{array}$} & Sand (\%) & 120 & 12.50 & 55.00 & 34.46 & 9.18 & 26.65 & -0.30 & -0.30 \\
\hline & Clay (\%) & 120 & 23.40 & 61.60 & 41.47 & 8.10 & 19.53 & 0.53 & 0.53 \\
\hline & Silt (\%) & 120 & 12.50 & 41.80 & 24.07 & 4.83 & 20.07 & 1.18 & 1.18 \\
\hline & $\mathrm{BD}\left(\mathrm{gr}_{\mathrm{cm}} \mathrm{cm}^{-3}\right)$ & 120 & 1.12 & 1.41 & 1.26 & 0.07 & 5.20 & 0.22 & 0.22 \\
\hline & $\mathrm{CaCO}_{3}(\%)$ & 120 & 2.92 & 39.43 & 21.27 & 7.86 & 36.97 & -0.68 & -0.68 \\
\hline & SOM (\%) & 120 & 0.15 & 14.24 & 2.80 & 2.12 & 75.67 & 3.83 & 3.83 \\
\hline & $\mathrm{pH}$ & 120 & 6.90 & 7.76 & 7.26 & 0.18 & 2.44 & 0.57 & 0.57 \\
\hline & $\mathrm{EC}\left(\mathrm{dS} \mathrm{m}^{-1}\right)$ & 120 & 0.17 & 2.15 & 1.31 & 0.29 & 22.28 & 0.21 & 0.21 \\
\hline
\end{tabular}

$\mathrm{BD}$ : bulk density; $\mathrm{CaCO}_{3}$ (calcium carbonate): lime content; SOM: soil organic matter; $\mathrm{pH}$ : soil reaction; EC: electrical conductivity; $\mathrm{N}$ : sample number, Min: minimum, Max: maximum, SD: standard deviation, CV: coefficient of variation (\%); Kur: kurtosis; Skew: skewness

species can survive in soils with high $\mathrm{CaCO}_{3}$ content, while A. xylobasis var. angustus species showed less resistance to this situation.

According to Duran (2013), the differences in the parent material and soil types play an important role in the determination of the diversity of plant communities and distribution. Soil $\mathrm{pH}$ values with $A$. anthylloides and A. lycius species varied between 6.90 and 7.76, while soil $\mathrm{pH}$ values with taxa $A$. xylobasis var. angustus varied between 5.58 and 7.64. When the study area soils were evaluated in terms of bulk density, it was suitable for plant growth with a minimum of $1.12 \mathrm{~g} . \mathrm{cm}^{-3}$ and a maximum of $1.41 \mathrm{~g} \cdot \mathrm{cm}^{-3}$. Singh et al. (1992) stated that the BD value of soil suitable for plant growth was $1.3 \mathrm{~g} . \mathrm{cm}^{-3}$. Bulk density dependent directly on soil clay content but ratio of bulk density depends indirectly on soil texture (Reichert et al., 2014; Suzuki et al., 2015). All of the investigated soils were salt-free according to the Tüzüner (1990).

\section{Desertification Status of Study Area}

As a result of the calculations made by using the desertification criteria and indicators outlined by the DIS4ME system in the study area, the DR in the forest areas where $A$. anthylloides and $A$. lycius species are distributed was the lowest with 0.49 (DR $<1.49$; no risk class) and the highest with 3.73 (2.50 < DR < 5.49; medium risk class), with average overall value of $2.20(1.50<D R<2.49$; low risk class) (Table 4). This illustrates that the forest areas where the $A$. anthylloides and $A$. lycius species grown are not highly affected by the desertification processes. However, in some sampling points in pine forests, DR increased to the medium risk class due to factors such as deteriorated vegetation structure (plant cover), increased clay content in soils, and soil properties changing because of erosion and high rock fragments. In the grassland areas in which A. xylobasis var. angustus species is distributed, DR varied between 5.01 and $5.42(2.50<\mathrm{DR}<5.49$; medium risk class) (Tab. 4). All sampling points in grassland areas where A. xylobasis var. angustus are distributed were classified as middle risk class, and DR values did not show much variation (CV 3.96\%, Table 4). Among the reasons for the high DR in grassland areas compared to forest areas are the presence of fine-textured soils with high clay content, anthropogenic activity, and exposure to grazing.

After calculating the DR for the study area, the ESAI of each sampling point was determined. The ESAI changed according to the distribution of the Astragalus L. species and land use type. ESAI values varied between 1.34 and 1.50 in forest areas where $A$. anthylloides and $A$. lycius species were distributed and ranged between 1.33 and 1.47 in pasture areas where $A$. xylobasis var. angustus 2as high fragile sensitivity class (F3 subclass; 1.33-1.37), and as medium critical sensitivity class (C2 subclass; 1.421.53), respectively.

The medium critical sensitivity class (C2), which is dominant in the study area, plays an important role in the desertification process here. This subclass covers degraded lands that threaten the surrounding lands due to their misuse (Kosmas et al., 1999). Furthermore, according to Parvari et al. (2011), critical areas (C1, C2, and C3) are very susceptible to degradation under any change that occurs in the delicate balance between climate and land use. In the event of any changes occurring in such areas, vegetation in the area may disappear and a decrease in biological potential may occur as a result of increased erosion. The areas where the fragile sensitivity class (F2), the other sensitivity class that was found in this study are the areas where deterioration can begin due to any change in the natural equilibrium, as a result of climate or anthropogenic effects (Kosmas et al., 1999; Giordano et al.,2002).

The main risk factors determined in the study area consist of (i) the type of vegetation characterized by a high risk of fire on south-facing slopes associated with low 
Tab. 4 Descriptive statistic of desertification risk.

\begin{tabular}{ccccccccc}
\hline \multirow{2}{*}{ Plant taxa } & Parameters & Min. & Max. & Mean & SD & Kur. & Skew. \\
\hline \multirow{2}{*}{ Aa and $A$ I } & DR & 0.49 & 3.73 & 2.20 & 0.71 & 0.07 & -0.38 & 32.35 \\
& ESAl & 1.34 & 1.50 & 1.41 & 0.05 & 0.09 & -1.24 & 3.46 \\
\hline \multirow{2}{*}{ Ax } & DR & 5.01 & 5.42 & 5.22 & 0.21 & 0.00 & -2.07 & 3.96 \\
& ESAl & 1.33 & 1.47 & 1.38 & 0.05 & 0.07 & -1.72 & 3.42 \\
\hline
\end{tabular}

Aa: A. anthylloides, Al: A. lycius, Ax: A. xylobasis var. angustus, DR: desertification risk, ESAl: environmentally sensitive area index, Min: minimum, Max: maximum, SD: standard deviation, CV: coefficient of variation (\%); Kur: Kurtosis; Skew: Skewness

annual rainfall and low plant cover, (ii) the type of vegetation characterized by low resistance to drought, and (iii) clayey soil texture with very low rock fragments. These identified risk factors are thought to cause the variation of types and subtypes of environmentally sensitive index individually or together and are also the most common desertification drivers in this study.

Results of Interaction Between Desertification Risk (DR) and Astragalus L. species

Correlation analysis was used to determine the relationship between DR and related variables (Tab. 5). As a result of the correlation analysis between DR and Astragalus L. species, the distribution of $A$. anthylloides $(r=-0.338, \mathrm{P}<$ $0.01)$ and $A$. lycius $(r=-0.354, \mathrm{P}<0.01)$ had a weak negative correlation with the DR. On the other hand, $A$. xylobasis var. angustus distribution had a high positive correlation ( $r=$ $0.744, \mathrm{P}<0.01)$ with DR.

\section{DISCUSSION}

Findings from this study contribute to the literature in many aspects. First, one of these contributions is to the environmentally sensitive area index (ESAl). The study results showed that the main risk factors in the study area were only affected by the vegetation quality index and the soil quality index although ESAI is obtained as a result of the evaluation of four quality indexes (soil, vegetation, climate, and management). This finding is consistent with the results of previous studies in the literature, and also confirms that desertification criteria and indicators should be obtained from site-specific local data in studies that determine the desertification risk (DR) and type of ESAI (Kosmas et al., 2006; Benabderrahmane and Chenchouni, 2010). Moreover, because there is no application for the management quality index in the study area, and also annual rainfall amount used in the climate quality index is the same in almost all sampling points, it has the same values throughout the area. Therefore, it can be said that these indicators were not effective in determining the type of ESAI. Similar results have been recently seen in other studies. For instance, Gül and Erşahin (2019) indicated that management and climate quality indicators are not useful for determining DR in semi-arid grassland and forest areas. This confirms that the desertification criteria and indicators should be obtained from site-specific local data in studies that determine the DR and type of ESAI (Kosmas et al., 2006; Benabderrahmane and Chenchouni, 2010).

Secondly, the differences in the use of these species as indicators for the assessment of the extent of desertification in environmentally sensitive areas were analyzed. Astragalus L. species has a wide ecological tolerance because of the easy distribution of their seeds (Böcük et al., 2009; Türe, 2003). According to Hanefi and Joufret (2008), this species plays a pioneering role during succession, and thus, temporal and spatial monitoring may well be important for land managers. In this respect, the study also supports the results of previous studies indicating that Astragalus L. species may be an indicator of desertification (e.g., Kadıoğlu et al., 2008; Niknam and Ebrahimzadeh, 2002). Also, in contrast to earlier studies, in order to determine the DR, it has been shown in this study that the three species of the genus Astragalus L. studied have different behavior. A. xylobasis var. angustus were positively correlated to DR. Since the positive relationship with DR will be the base for the determination of desertification, $A$. xylobasis var. angustus has been determined as the main indicator plant species. This finding reveals the need to consider the distribution areas of plant species, especially for the determining the DR. Similarly, in the study, when the areas where plant species spread are evaluated, it has been determined that $A$. anthylloides and $A$. lycius are on the forest floor and A. xylobasis var. angustus is in grassland areas. Compared to two other Astragalus L. species, it is

Tab. 5 Correlation analysis between DR and three endemic Astragalus L. species.

\begin{tabular}{|c|c|c|c|c|c|c|}
\hline Parameterv & $P C$ & $\mathrm{Aa}$ & $\mathrm{Al}$ & $A x$ & OS & DR \\
\hline$P C$ & 1.000 & 0.114 & -0.090 & $0.274\left(^{* *}\right)$ & $0.433\left(^{* *}\right)$ & 0.028 \\
\hline $\mathrm{Aa}$ & 0.114 & 1.000 & $-0.294\left(^{(* *}\right)$ & $\left.-0.3000^{(* *}\right)$ & $\left.-0.2877^{(* *}\right)$ & $\left.-0.338{ }^{(* *}\right)$ \\
\hline Al & -0.090 & $-0.294(* *)$ & 1.000 & $\left.-0.3333^{(\star *}\right)$ & -0.094 & $-0.354\left(^{(*}\right)$ \\
\hline$A x$ & $0.274\left(^{\star *}\right)$ & $-0.300\left(^{* \star}\right)$ & $\left.-0.3333^{* *}\right)$ & 1.000 & $0.342\left(^{* \star}\right)$ & $0.744\left(^{* \star}\right)$ \\
\hline OS & $0.433\left(^{* *}\right)$ & $-0.287\left(^{* \star}\right)$ & -0.094 & $0.342\left(^{* *}\right)$ & 1.000 & $0.427\left(^{* \star}\right)$ \\
\hline DR & 0.028 & $-0.338(* *)$ & $-0.354(* *)$ & $0.744\left(^{* \star}\right)$ & $0.427\left(^{* *}\right)$ & 1.000 \\
\hline
\end{tabular}

PC: Plant cover (\%); Aa: A. anthylloides Lam., Al: A. lycius, Ax: A. xylobasis var. angustus, OS: Other species (It refers to the steppe characteristic herbaceous taxa distributed within quadrats); DR: desertification risk), ** $\mathrm{P}<0,01$. 
an important indicator that A. xylobasis var. angustus has adapted better to stepper areas (Dölarslan et al., 2017).

At the same time, the characteristics and properties of the soil are also important components that affect DR and plant growth (Peng et al., 2015). In the pine forest where $A$. anthylloides and $A$. lycius are distributed, there are individuals of 30-40 years old Black pine. In this area, vegetation quality indexes such as plant cover and soil properties, e.g. soil organic matter (SOM) and $\mathrm{pH}$, which affect erosion protection better, score better compared to grassland areas where A. xylobasis var. angustus is distributed. The SOM content is the most important indicator of soil quality and sustainable ecogeomorphological systems (Sparling 1991; Imeson 1995). Pardini et al. (2000) and Nunes (2011) described the limit value of SOM to be $1.70 \%$ and the beginning of desertification. According to this indicator property, the average SOM content of $2.53 \%$ detected for this study area confirms that the area faces desertification imminently. Rock fragments are one of the other main risk factors affecting desertification in the study area and have a critical effect on soil hydrological properties, runoff, water conservation, plant growth, soil, and vegetation degradation by soil-water erosion (Poesen et al. 1998; Kosmas et al. 2003). In addition, rock fragments on the soil surface protect the areas from desertification by limiting the evaporation of soil water and supporting plant growth (Kosmas et al. 2003). This situation confirms that there is a high desertification sensitivity because of drought resistance and rock fragments found in the study area due to the distribution of Astragalus L. species.

The topography is the other major main risk factor affecting desertification in the study area. When the relationship between topography, the distribution of Astragalus L. species, and DR evaluated together, desertification sensitivity is low in flat and nearly flat areas where soil development is sufficient. However, the risk is high in the upper part of the slope bases and the lower drainage paths of the slope pastures where A. xylobasis var. angustus are dispersed (Desertlinks, 2004).

\section{CONCLUSIONS}

This study illustrates that the differences in some soil characteristics of the plant species may be different in the growing environment requirements of the same family according to genus and species under the same climatic conditions. In addition, soil organic matter (SOM) and calcium carbonate $\left(\mathrm{CaCO}_{3}\right)$ can be used as indicator soil properties concerning the distribution of plants.

The data obtained from this study also implies that desertification indicator system for Mediterranean Europe (DIS4ME system) may be applied in similar areas to evaluate the effects of plant taxa on desertification tendency, to combat desertification, and to determine of desertification criteria-indicators and desertification processes.

\section{ACKNOWLEDGEMENTS}

This study was supported by the Scientific Research Projects Coordination Unit of Çankırı Karatekin University, Project number: OF200217B24.

\section{AUTHORSHIP CONTRIBUTION}

\author{
Project Idea: EG and MD \\ Funding: $\mathrm{EG}$ \\ Database: $\mathrm{EG}$ and $\mathrm{MD}$ \\ Processing: EG \\ Analysis: EG \\ Writing: $E G$ and MD \\ Review: EG and MD
}

\section{REFERENCES}

ADAMO, S.B.; CREWS-MEYER, K.A. Aridity and desertification: exploring environmental hazards in Jáchal, Argentina. Applied Geography, v.26, n.1, p.61-85, 2006

AKPULAT, H.A.; ÇELIK, N. A new subspecies of Astragalus L. (section Caprini DC. Fabaceae) from Turkey. Botanical Journal of the Linnean Society, v.155, n. 2, p. 227-230, 2007.

AN, P.; INANAGA, S.; ZHU, N.; LI, X.; FADUL, H. M.; MARS, M. Plant species as indicators of the extent of desertification in four sandy rangelands, African Journal of Ecology, v. 45, n. 1, p.94-102, 2007.

BASSO, F.; BOVE, E.; DUMONTET, S.; FERRARA, A.; PISANTE, M.; QUARANTA G.; TABERNER, M. Evaluating environmental sensitivity at the basin scale through the use of geographic information systems and remotely sensed data: An example covering the Agri basin Southern Italy, Catena, v. 40,p. 19-35, 2000

BENABDERRAHMANE, M.; CHENCHOUNI, H. Assessing environmental sensitivity areas to desertification in Eastern Algeria using Mediterranean desertification and land use "MEDALUS" model, The International Journal of Sustainable Water and Environmental Systems, v.1, n. 1, p. 5-10, 2010.

BLAKE, G. R.; HARTGE, K. H. Bulk density. In: KLUTE, A. Methods of soil analysis: Part 1. Physical and mineralogical methods. American Society of Agronomy and Soil Science Society of America, 1986. p. 363-375.

BOCUK, $\mathrm{H}_{\text {: }}$ TURE, $\mathrm{C}$ : KETENOĞLU, O. Plant Diversity and Conservation of the Northeast Phrygia Region under the Impact of Land Degradation and Desertification (Central Anatolia, Turkey). Pakistan journal of botany, n. 41, v. 5, p. 2305-2321. 2009

BOUABID, R.; ROUCHDI, M.; BADRAOUI, M., DIAB, A., LOUAFI, S. Assessment of land desertification based on the MEDALUS approach and elaboration of an action plan: the case study of the Souss River Basin, Morocco. In: ZDRULI, P.; PAGLIAI, M., KAPUR, S.; CANO, A.F. Land Degradation and Desertification: Assessment, Mitigation and Remediation, Springer, 2010. p. 131-145.

BRANDT, J.; GEESON, N. Desertification indicator system for Mediterranean Europe: Science, stakeholders and public dissemination of research results. In Dykes, A.P; Mulligan, M.; Wainwright, J. Monitoring and Modelling Dynamic Environments. 2015. p.121-154.

BUDAK, M.; GÜNAL, $\mathrm{H}_{\text {: }}$ ÇELİK, İ.; YILDIZ, $\mathrm{H}_{\text {: }}$ ACIR, N.; ACAR, M Environmental sensitivity to desertification in northern Mesopotamia; application of modified MEDALUS by using analytical hierarchy process. Arabian Journal of Geosciences, v. 11, n. 17, p.481, 2018.

CAMCI CETIN, S: KARACA, A. HAKTANIR, K: YILDIZ, $\mathrm{H}$. Global attention to Turkey due to desertification, Environmental Monitoring and Assessment, v. 128, n. $1-3$, p. $489-493,2007$.

DAVIS P.H. Flora of Turkey and The East Aegean Islands Vol: I-IX, United Kingdom, 1965. $567 \mathrm{p}$

DAVIS P.H. Flora of Turkey and The East Aegean Islands (Supplement) Vol:10, United Kingdom,1988. 567 p.

DE SOYZA, A. G.; WHITFORD, W. G.; HERRICK, J. E.; VAN ZEE, J. W.; HAVSTAD K. M. Early warning indicators of desertification: examples of tests in the Chihuahuan Desert. Journal of Arid Environment, v.39, n. 2, p.101-112, 1998. 
DEMIR, U.; KESKIN , B. Some soil properties in inside/outside of canopy and different soil depth of gum tragacanth (Astragallus gummifer L.), Journa of The Institute of Science and Technology (JIST) Publishing Policies, v. 6 n. 4, p.127-133, 2016.

DESERTLINKS. Desertification Indicator System for Mediterranean Europe (DIS4ME). Available at: https://esdac.jrc.ec.europa.eu/public_path/shared folder/projects/DIS4ME/introduction.htm, 2004. Accessed in: October 23 th 2020.

DINDAROGLU, T. Resistance to the reclamation of environmentally sensitive areas through the establishment of a new forest ecosystem, Fresenius Environmental Bulletin, v. 24, n. 4, p.1195-1203, 2015.

DÖLARLAN, M., GÜL, E., ERŞAHINN, S. Determination of the relationship between plant species richness, diversity and desertification tendency in semi-arid areas: Example of Çankırı-Eldivan, 2014-2015. (Supporting Organization: TÜBITAK-TOVAG / 1002-1140707), 2015.

DÖLARSLAN, M.;GÜL, E.; ACAR, E.; TÜRKTAŞ, M. A phylogenetic perspective on the influence of ecological attributes on selected species of Astragalus. Écoscience, v. 24, v.3-4, p.105-113. 2017

DREGNE, H. E. Land degradation in the drylands. Arid Land Research and Management, v. 16, n. 2, p. 99-132, 2002.

DURAN, C. The role of mountainous areas on plant diversity of Turkey. Research Journal of Biology Sciences, v. 6, n. 1, p. 72-77, 2013.

ERKUL KARAMAN, S.; AYTAÇ, Z. Astragalus yukselii (Leguminosae), a new species from Turkey. Turkish Journal of Botany, v. 37, n. 5, p.836-840, 2013

GEE, G. W.; BAUDER, J. W. 1986. Particle-size analysis. In: KLUTE, A. Methods of soil analysis: Part 1. Physical and mineralogical methods. America Society of Agronomy and Soil Science Society of America, 1986. p. 383-411.

GEESON, N.; BRANDT, J; QUARANTA, G.; SALVIA, R. Designing a public webbased information system to illustrate and disseminate the development and results of the DESIRE Project to combat desertification, Environmenta Management, v. 54, n. 5, p. 1043-1055, 2014

GIORDANO, L: GIORDANO, F: GRAUSO, S.: IANNETTA, M.: SCIORTINO, M ROSSI, L.; BONATI, G. Identification of areas sensitive to desertification in Sicily Region. Identifi cation of areas sensitive to desertifi cation in Sicily Region, ENEA, Rome, Italy, 2007. p. 1-16

GONZALEZ, P. Desertification and a shift of forest species in the West African Sahel. Climate Research, v.17, n.2, p. 217-228, 2001.

GÜL, E.; ERSAHIN, S. 2019. Evaluating the desertification vulnerability of a semiarid landscape under different land uses with the environmenta sensitivity index, Land Degradation and Development, v. 30, p811-823, 2019.

GÜL, E.; ERŞAHIN, S. Modeling Desertification Risk in Semi-Arid Natura Pine Forests, Anatolian Journal of Forest Research, v. 3, n. 1, p.39-49, 2017

GUTTERMAN, Y. Strategies of seed dispersal and germination in plants inhabiting deserts, The Botanical Review, v. 60, n. 4, p.373-425, 1994.

HANAFI, A.; JAUFFRET, S. Are long-term vegetation dynamics useful in monitoring and assessing desertification processes in the arid steppe southern Tunisia. Journal of Arid Environments. v. 72, n.4, p 557-572. 2008

HUANG, S.; SIEGERT, F. Land cover classification optimized to detect areas at risk of desertification in North China based on SPOT VEGETATION imagery, Journal of Arid Environments, v. 67, n. 2, p.308-327, 2006.

ILCIM, A.; BEHÇET, L. Astragalus topalanense (Fabaceae), a new species from Turkey. Turkish Journal of Botany. v.40, n. 1, p.74-80. 2016.

IMESON, A. The physical, chemical and biological degradation of the soil. In: Fantechi, E.: Denis, D. P. Balabanis, P. Rubio J. I. Desertification in a European Context: Physical and socio-economic aspects, European Commission, Directorate-General Science, Research and Development, EUR 151415EN.1995. p. 153-168.

KAÇMAZ, S. Plant of Unknown Value: Geven. Ecology Magazine, v. 13, p. $88-89,2007$.

KADIOĞLU, B.; KADIOĞLU, S.: TURAN, Y. The importance and the differan usages of gumtragacanth (Astragalus $s p$.$) , Alinteri Journal of Agriculture$ Science, v. 14, n. 1, p.17-26, 2008

KHARIN, N.; NECHAEVA, N. T.; NIKOLAEV, V. N.; BABAEVA, T.; DOBRIN, L. G. BABAEV, A.; ORLOVSKY, N. S.; REDZHEPBAEV, K.; KIRSTA, B. T.; NURGELDYEV O. N. A methodological principles of desertification processes assessment and mapping, arid lands of Turkmenistan taken as example. Ashkhabad Australian Journal of Basic and Applied Sciences, v. 2, p.157-164, 1985.

KOSMAS, C.; FERRARA, A.; BRIASOULI, H.; IMESON, A. Methodology for mapping environmentally sensitive areas (ESAs) to desertification. In KOSMAS, C.: KIRKBY, M.; GEESON, N. The Medalus project Mediterranean desertification and land use. Manual on key indicators of desertification and mapping environmentally sensitive areas to desertification, Project Report, 1999.p.31-47.
KOSMAS, C.; TSARA, M.; MOUSTAKAS, N.; KARAVITIS, C. Identification of indicators for desertification, Annals of Arid Zone, v. 42, p.393-416, 2003.

KOSMAS, C.; TSARA, M.; MOUSTAKAS, N.; KOSMA, D.; YASSOGLOU, N Environmentally sensitive areas and indicators of desertification, In KEPNER WG. RUBIO JI. MOUAT. DA. PEDRAZZINI F Desertification in the Mediterranean Region. A security issue: Springer, 2006, pp. 525-547,

MABBUTT, J. A. A new global assessment of the status and trends of desertification, Environmental Conservation, v. 11, n. 2, p.103-113, 1984

MCLEAN, E. O. Soil pH and Lime Requirement. In: PAGE, A.L., Methods of Soil Analysis. Part 2. Chemical and Microbiological Properties, American Society of Agronomy, Soil Science Society of America, Madison, 1982. p. 199-224.

MORIANOU, G. G.; KOURGIALAS, N. N.; PSARRAS, G.; KOUBOURIS, G. C. Mapping sensitivity to desertification in Crete (Greece), the risk for agricultural areas, Journal of Water and Climate Change, v. 9, n. 4, p.691$702,2018$.

NELSON, D. W.: SOMMERS, L. E. Total carbon, organic carbon, and organic matter. Methods of soil analysis. Part 2. Chemical and Microbiological Properties, American Society of Agronomy, Soil Science Society of America, Madison, 1982. p. 539-579.

NELSON, R. E. Carbonate and gypsum. Methods of soil analysis. Part 2. Chemical and microbiological properties Madison: American Society of Agronomy and Soil Science Society of America. 1982. pp. 181-196.

NIKNAM, V.; EBRAHIMZADEH, H. Phenolics content in Astragalus species, Pakistan Journal of Botany, v. 34, n. 3, p. 283-289, 2002.

NUNES, A. N.; DE ALMEIDA, A. C.; COELHO, C. O. Impacts of land use and cover type on runoff and soil erosion in a marginal area of Portugal. Applied Geography, v.31, n. 2, p. 687-699.2011.

PARDINI, G.; DUNJÓ, G.; BARRENA, R.; GISPERT, M. Land use effects on soil response to runoff generation and sediment yield in the Serra de Rodescatchment Alt Emporà, NE Spain. In: Rubio, J L. Asins, S. Andreu, V.: Paz, J. M.; Gimeno, E., Man and soil at the third millennium (pp. 290e298). Valencia: ESSC- European Society of Soil Conservation, $28 \mathrm{March}-1$ April. Book of abstracts, Valencia, Spain. 2000

PARVARI, S. H.; PAHLAVANRAVI, A.; NIA, M.; REZA, A.; DEHVARI, A.i PARVARI, D Application of methodology for mapping environmentally sensitive areas (ESAs) to desertification in dry bed of Hamoun Wetland (Iran), Ecopersia, v. 0, n. 1, p.65-80, 2011

PENG. J.; CAO, F.; LIU, Z.; CAO, J.; WU, L.; LI, M.; DONG, X. A correlation analysis of rocky desertification grades, plant diversity and soil factors in Central Hunan of China, Acta Scientia et Intellectus, v. 1, n. 2, p. 45 57,2015

POESEN, J. W; WESEMAEL, B. V; BUNTE, K.; BENET, A. S. Variation of rock fragment cover and size along semiarid hillslopes: a case-study from southeast Spain. Geomorphology. v. 23, n.2-4, p. 323-335. 1998

RASMY, M.; GAD, A.; ABDELSALAM, H.; SIWAILAM, M. A dynamic simulation model of desertification in Egypt, The Egyptian Journal of Remote Sensing and Space Science, v. 13, n. 2, p. 101-111, 2010.

REICHERT, J.M., BERVALD, C.M.P.; RODRIGUES, M.F.; KATO, O.R.; REINERT, D.J. Mechanized land preparation in eastern Amazon in fire-free forestbased fallow systems as alternatives to slash-and-burn practices: Hydraulic and mechanical soil properties. Agriculture, Ecosystems and Environment, v.192, p.47-60.2014.

SALVATI, L. BAJOCCO, S. Land sensitivity to desertification across Italy: Past, present, and future. Applied geography, v. 31, p. 223-231, 2011.

SINGH, K. K.; COLVIN, T. S.; ERBACH, D. C.; MUGHAL, A. Q. Tilth index: an approach to quantifying soil tilth, Transactions of the American Society of Agricultural Engineers, v.35, n. 6, p.1777-1785, 1992

Soil Survey Staff. Soil survey manual. USDA. Handbook No:18. Washington D.C. 1993.p.503.

SPARLING, G. D. Organic matter carbon and microbial biomass as indicators of sustainable land use. Technical Papers. In: Elliot, C. R.; Latham, M.; Dumanski, J. Evaluation for sustainable and management in the developing world, Vol. 2. Bangkok, Thailand: IBSRAM. Proceedings No. 12, IBSRAM. 1991

SPSSINSTITUTEINC. SPSS Base 20.0 User's Guide. SPSS Inc., Chicago, IL Search Pub Med, 2012

SUZUKI, L.E.A.S., Reichert, J.M., Reinert, D.J. de Lima, C.L.R. Degree of compactness and mechanical properties of a subtropical alfisol with eucalyptus, native Forest, and grazed pasture, Forest Science, v. 61, n. 4, p.716-722. 2015.

TUBITAK. Desertification report of Turkey, 2015.

TÜRE, C. An Investigation on the Weed Diversity in Some Agricultural Fields of Inegöl (Bursa) and its Environments. Turkish Weed Science, v. 6, n. 1, p. 48-59.2003. 
TÜRKEŞ, M. A detailed analysis of the drought, desertification and the united nations convention to combat desertification, The Journal of Marmara European Research, v. 20, n. 1, p. 7-55, 2012

TÜZÜNER, A. Soil and water analysis laboratories handbook. Ministry of Agriculture, Forestry and Rural Affairs, General Directorate of Rural Services, 1990

ULUOCAK, N. Soil preserving natural vegetation and indicator events, Journa of the Faculty of Forestry Istanbul University, v. 30, n. 1, p. 64-85, 1980.

UNCCD. United Nations Convention to Combat Desertification in those countries experiencing serious drought and/or desertification, particularly Africa, 1995.
VANMAERCKE, M.; POESEN, J.; MAETENS, W.; DE VENTE, J.; VERSTRAETEN, $G$. sediment yield as a desertification risk indicator, Science of the Total Environment, v. 409, n. 9, p.1715-1725, 2011

YÜCETÜRK, G. Artifical Marble Used in the Physicomchanical Properties of Quartz and Calsite, SDU International Journal of Technological Science, v. 2, n. 3, p. $72-80,2010$

ZHAO, C.; GAO, J.; HUANG, Y.; WANG, G.; XU, Z. The contribution of Astragalus adsurgens roots and canopy to water erosion control in the water-wind crisscrossed erosion region of the Loess Plateau, China, Land Degradation and Development, v. 28, n. 1, p.265-273, 2017 